\title{
5 years of monitoring of zooplankton community dynamics in a newly impounded sub-tropical reservoir in Southeast Asia (Nam Theun 2, Lao PDR)
}

\author{
Suivi de cinq ans de la dynamique des communautés \\ zooplanctoniques d'un réservoir subtropical nouvellement mis \\ en eau dans le sud-est Asiatique (Nam Theun 2, Laos)
}

\author{
S. Descloux ${ }^{(1)}$, M. Cottet ${ }^{(2)}$ \\ (1) EDF - Hydro Engineering Centre Sustainable Development Department Savoie-Technolac, \\ 73373 Le Bourget-du-Lac, France \\ stephane.descloux@edf.fr \\ (2) Nam Theun 2 Power Company Limited (NTPC), Environment \& Social Division - Water Quality \\ and Biodiversity Dept. - Gnommalath Office, PO Box 5862, Vientiane, Lao PDR
}

\begin{abstract}
The zooplanktonic community of the Nam Theun 2 Reservoir, newly impounded, located in Lao PDR was monitored from 2009 to 2013. Five sampling stations distributed on the surface of the reservoir were sampled on a monthly basis. Results were interpreted to assess the spatial and temporal variability of the communities and to identify environmental factors such as physical or water chemical parameters influencing communities. The zooplanktonic community was dominated by Copepods over the study period and was characterized by low densities and biomasses reflecting low productivity conditions. The spatial heterogeneity of the zooplanktonic community observed along a longitudinal gradient disappeared rapidly after the beginning of the operational phase in 2010 and tended to stabilize. The results also highlighted a seasonal variability explained by a phytoplankton-based food chain. Zooplankton communities were significantly and negatively driven by hydraulic factors, such as the mixing period, or water quality factors, such as water temperature or the depth of the oxycline. This zooplankton community must be evaluated in order to anticipate the food availability for zooplanktivorous fish before developing a fish management plan.
\end{abstract}

Key words - sub-tropical reservoir, Southeast Asia, Copepods, spatial heterogeneity, mixing

Résumé - La communauté zooplanctonique du réservoir de Nam Theun 2, nouvellement mis en eau et situé dans la République démocratique du Laos, a été suivie de 2009 à 2013. Cinq stations d'échantillonnage réparties sur la surface du réservoir ont été échantillonnées à une fréquence mensuelle. Les résultats ont été interprétés pour évaluer les variations spatiales et temporelles de la communauté et d'identifier les facteurs environnementaux tels que 


\begin{abstract}
les paramètres physiques ou chimiques de l'eau influençant les communautés. La communauté zooplanctonique était dominée par les Copépodes pendant la période d'étude et a été caractérisée par de faibles densités et biomasses reflétant des conditions de faible productivité. L'hétérogénéité spatiale de la communauté zooplanctonique observée le long d'un gradient longitudinal a disparu rapidement après le début de la phase d'exploitation en 2010 et la communauté a eu tendance à se stabiliser. Les résultats ont également mis en évidence un effet saisonnier expliqué par une chaîne alimentaire basée sur le phytoplancton. La communauté zooplanctonique a été sous l'influence significative de facteurs hydrauliques comme la période de mélange des eaux ou de facteurs de qualité d'eau comme la température de l'eau ou de la profondeur de l'oxycline. Cette communauté zooplanctonique doit être évaluée afin d'anticiper la nourriture disponible pour les poissons zooplanctophages et avant la mise en place d'un programme de gestion de la ressource piscicole.
\end{abstract}

Mots clés - réservoir sub-tropical, Asie du sud-est, Copépodes, hétérogénéité spatiale, mélange

\section{INTRODUCTION}

Freshwater zooplankton communities have been described in tropical and sub-tropical areas in numerous studies in South America (Matsumura-Tundisi \& Tundisi, 1976; Bini et al., 1997; Starling, 2000; Fernando, 2002; Bonecker et al., 2007; Lansac-Tôha et al., 2008; Sousa et al., 2014), Africa (Uku \& Mavuti, 1994; Mageed \& Heikal, 2006; Fetahi et al., 2011) and Asia (Dussart et al., 1984). They are, in lentic zones, generally driven by environmental factors such as turbidity, nutrient and dissolved oxygen concentrations or phytoplankton density and diversity (Hart, 1990; Schulz \& Sterner, 1999). These factors fuel the spatial heterogeneity in a water body and enhance temporal variations of the zooplankton communities (Bini et al., 1997; Seda \& Devetter, 2000; Espindola et al., 2000; Bernot et al., 2004).

The few available data in Asia mainly focused on systematics. Dussart et al. (1984) indicated that Rotifera,
Cladocera and Copepods are composed of few species and that the Cyclopoida Copepod could represent high densities. They also specified that the common limnetic species can use the entire range of habitat types. However, scarce data on zooplankton community dynamics exists in Southeast Asia (Dussart et al., 1984), and even less in the Mekong River and its tributaries. Studies on reservoirs remained also inexistent in Lao PDR.

The number of new reservoirs in Southeast Asia is increasing to face the growing energy demand. In 2009, The Mekong River Commission (MRC) estimated that more than $70 \%$ of a total 124 existing, under construction and potential projects in the Lower Mekong Basin will be located in Lao PDR (MRC, 2010). The impoundment of the Nam Theun 2 (NT2) Reservoir in 2008 led to a profound changes in aquatic communities (Cottet et al., same issue; Martinet et al., same issue) resulting in a modification of the trophic web structure. Phytoplankton and zooplankton, respectively 
primary and secondary producers are key components of this new ecosystem, influencing the entire food web (Hairston \& Fussman, 2002; Rennella \& Quirós, 2006; Araujo et al., 2008). The understanding of the temporal and spatial evolution of zooplankton community appears all the most important that newly created reservoirs play an important role for the local populations depending primarily on fish as protein resources. It is highly important to understand and assess the availability of zooplankton for the trophic chain and thus studies are required before implementing any fisheries management programmes.

In this context, the first objective of the study was to assess the intra and inter-annual evolution of the zooplankton community since the NT2 Reservoir impoundment based on density and biomass estimations of the main taxonomic groups. The second objective was to identify the main environmental parameters which influenced these zooplankton communities.

\section{MATERIAL AND METHODS}

\subsection{Sampling strategy}

\subsubsection{Study area}

The NT2 Project is a trans-basin hydro-power scheme located in Khammouane Province, central Lao PDR (Fig. 1). The water coming from the NT2 Reservoir (Nakai Plateau - Nam Theun watershed) is diverted to the Xe Bangfai River southwards (Xe Bangfai watershed). The impoundment of the reservoir was initiated in April 2008. Commercial operation started in April 2010.
Since then, the average retention time of the water in the reservoir is estimated to be approximately 6 months on the basis of the production of 6000 GWh.year $^{-1}$. The NT2 Reservoir covers a surface area of $489 \mathrm{~km}^{2}$ at its full supply level and potentially decreases to a minimum of $86 \mathrm{~km}^{2}$ at the end of the dry season (Descloux et al, same issue). The reservoir flooded almost $70 \%$ of dense to light forest, $23 \%$ of degraded forest, riparian forest and agricultural soils and the last $7 \%$ were composed of water system, swamps and villages (Descloux et al., 2011). The reservoir is qualified as a dendritic and is relatively shallow with an average depth of $8 \mathrm{~m}$ (Chanudet et al., 2012). The main tributaries of the reservoir are the Nam Xot, the Nam Theun and the Nam On Rivers. The climate is moist sub-tropical with a warm-wet (WW) season (June to October), a cool-dry (CD) season (November to February) and a warmdry (WD) season (March to May). The CD season is also characterized by wind events. During this season and because of the turbulences linked to the wind, the water column is mixed (mixing period). This mixing period occurs for a few weeks between November and February. Then, the NT2 Reservoir is defined as a monomictic reservoir with thermal and oxygen stratification occurring during the dry and warm seasons. Detailed features of this project are described in Descloux et al. (same issue).

\subsubsection{Monitored stations}

The sampling strategy covers the spatial heterogeneity of the reservoir. Zooplankton was monitored in the NT2 Reservoir on a monthly basis (Fig. 1) 


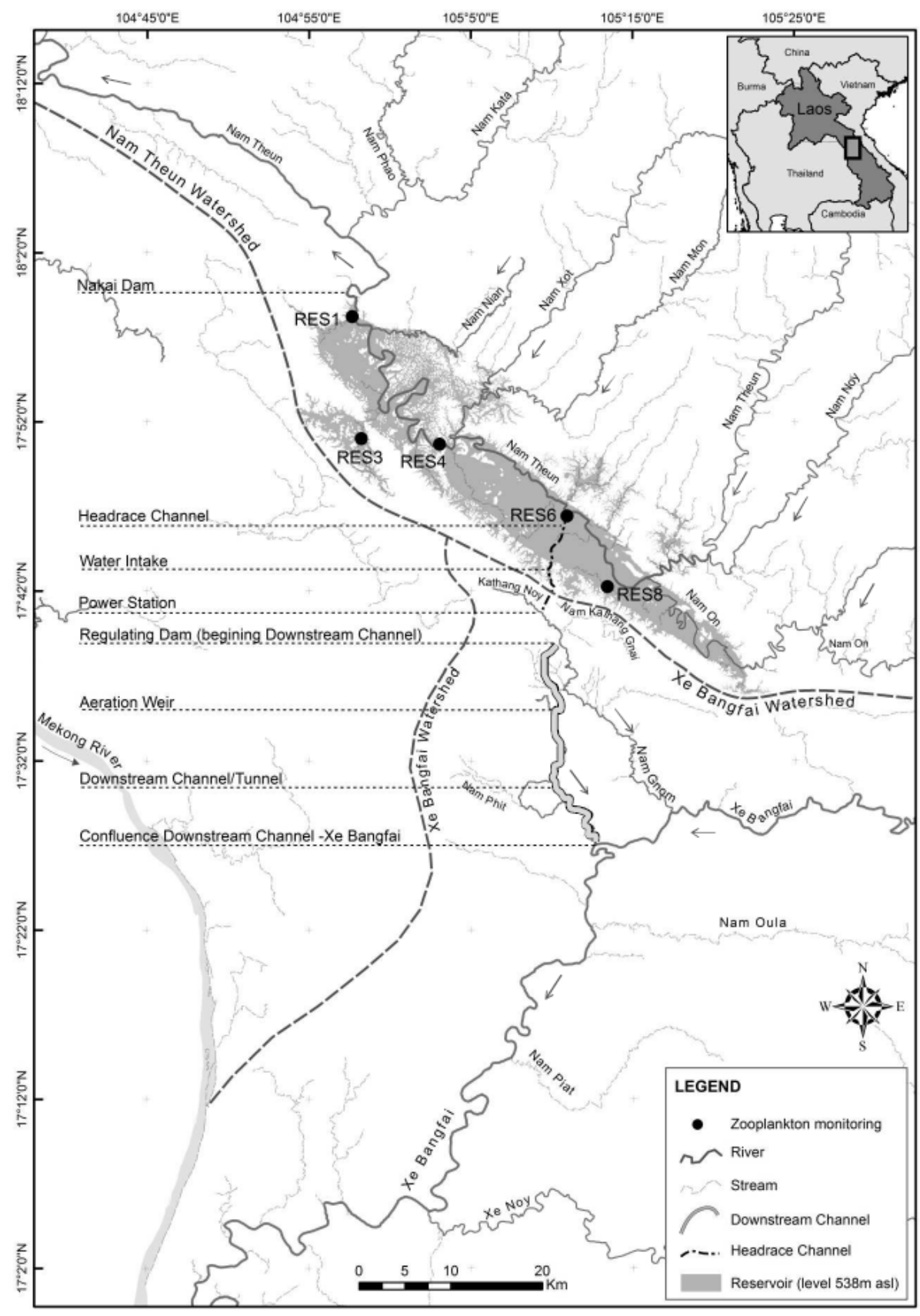

Fig. 1. Zooplankton communities monitoring stations.

Fig. 1. Stations de suivi des communautés zooplanctoniques. 
from February 2009 to December 2013 at three stations (i) RES 1 is the deepest station situated just upstream to the Nakai Dam (ii) RES4 is situated at the former Nam Theun River thalweg, the area is surrounded by submerged medium forest and (iii) RES6 is located at the former Nam Theun River thalweg near the North shore of the reservoir near the headrace channel. Since May 2013, RES6 station has been removed from the monitoring because of its similarity with RES8. Two stations were added in June 2009 to include a wider range of habitat (i) RES3 is situated in a sheltered and shallow area in a submerged dense forest and (ii) RES8 is situated in an open area outside the former Nam Theun River thalweg on the southern shore of the reservoir.

\subsubsection{Environmental parameters}

Since 2009, in situ physico-chemical parameters (depth, oxycline depth, surface dissolved oxygen (DO), surface water temperature, and surface water conductivity) were measured with a multi-parameter probe (Quanta, Hydrolab; the analytical methods with the associated limits of detection and uncertainties can be found in Chanudet et al., same issue). Water samples were collected in the euphotic zone defined by the Secchi disk (2.5 $x$ Secchi depth in $\mathrm{m}$ ). A total of 5 samples of $1 \mathrm{~L}$ were collected with a Niskin bottle at equidistant depths covering the entire euphotic zone and were mixed together. One litre of the mixed water was collected for chlorophyll a (Chlo a) analysis (Lorenzen's method). A sample of $250 \mathrm{~mL}$ was collected for chemical analyses which included Total phosphorus (Ptot, spectrophotometry), Total nitrogen (Ntot, spectrophotometry). All of the analyses followed the American Standards for Water Quality (APHA standards, 1995). Meteorological data (rain, wind) were recorded at RES4 and are detailed in Descloux et al. (same issue).

\subsubsection{Zooplankton sampling}

Zooplankton were collected vertically with a plankton net $(50 \mu \mathrm{m}$ mesh size) from $1 \mathrm{~m}$ below the oxycline to the surface to include organisms colonizing this area. All samples were preserved in $75 \%$ alcohol for further laboratory analysis.

\subsection{Laboratory analysis}

\subsubsection{Zooplankton analysis}

At laboratory, samples were carefully washed on a $50 \mu \mathrm{m}$ mesh size sieve, collected and diluted to a final volume of $150 \mathrm{~mL}$. This final volume of sample was chosen because (i) it allows a good repartition of individuals during the mixing step; (ii) it avoids aggregation between individuals and then a rapid sedimentation; (iii) it avoids an overload of the sample in case of abundant and large phytoplankton cells (e.g. Peridinium spp.) and (iv) it allows a good constancy between subsamples, collected with a $5 \mathrm{~mL}$ micro-pipette.

The identification of the taxa was realized at relatively coarse level mainly because of the high number of samples. These groups are the Cyclopoids, Calanoids, Cladocera, Nauplii stage (mainly composed by Copepods), Rotifer, and Ostracoda. 


\subsubsection{Zooplankton Sub-counting technique}

Seven sub-samples of $5 \mathrm{~mL}$, collected from the homogenized $150 \mathrm{~mL}$ sample, were counted on a counting plate under stereomicroscope. This total of $35 \mathrm{~mL}$ was chosen because it resulted in extrapolated densities with an error less than $5 \%$ for large individuals and $10 \%$ for small individuals compared to the real abundance (test realized with extrapolation on sub-counting and total sample counting: data not shown). This error range remains acceptable compared to the literature (Frontier, 1972). Furthermore, this number of sub-samples allows the observation of rare groups. Finally, if less than 200 individuals in the first $35 \mathrm{~mL}$ for a main group defined above were counted; additional counts of $5 \mathrm{ml}$ continues until a minimum of 200 individuals was reached. Finally, total densities (ind. $\mathrm{L}^{-1}$ ) are reported according to the sub-counting factor and the total volume of the water column sampled on site.

\subsubsection{Zooplankton biomass estimation}

An estimation of the mean dry weight (DW) of each zooplankton group was established for the NT2 Reservoir. This estimation was based on size of individuals which was defined as (i) the maximum length for Ostracoda and Rotifera (ii) the length from the head until the tail for Copepods and Nauplii and finally (iii) length from the head until spine for Cladocera. For Rotifer, Nauplii, and Ostracoda all individuals collected for the biomass estimation were measured, counted and kept in a sample for further analysis. Copepods and Cladocera were measured and separated according to different size classes (Tab. I). Each group sample was dried at $60{ }^{\circ} \mathrm{C}$ during 24 hours and weighed $(\mu \mathrm{g})$ on a micro-balance after being cooled in a desiccator. Then, biomasses were expressed as mean dry weight (DW) in $\mu \mathrm{g} \cdot \mathrm{L}^{-1}$. A comparison with literature data on zooplankton biomasses showed that the estimations of the biomasses of the NT2 zooplankton groups are reliable (Tab. I).

For monthly routine analysis, 30 individuals of Cladocera, Cyclopoids and Calanoids were measured to estimate the total biomass of each group. For the other groups, the mean DW was multiplied by the number of the individuals found in the sample. Finally, total biomasses ( $\left.\mu \mathrm{g} . \mathrm{L}^{-1} \mathrm{DW}\right)$ are reported according to the sub-counting factor and the total volume of the water column sampled on site.

\subsection{Data analysis}

Densities, biomasses and relative densities of each group were used to describe the spatial and temporal evolution of the community (GraphPad Software). Non-parametric tests of Kruskal-Wallis were used to compare the densities and biomasses among monitoring stations and years. Pairwise comparisons were done following the Dunn procedure. Zooplankton communities and environmental relations were studied through Principal Component Analysis (PCA). The PCA was undergone on a matrix including the biomass of the zooplankton groups, trophic factors (nutrient concentrations and Chlo a concentrations), 
Table I. Mean dry weight $(\mu \mathrm{g})$ of zooplankton groups according to the size class and comparison with available dry weight in literature. ${ }^{*}=$ according to the species, $\mathrm{x}=$ size of the individual and $\mathrm{d}=\mathrm{mean}$ size of individual used for dry weight estimation.

Tableau I. Poids sec moyen $(\mu \mathrm{g})$ des groupes zooplanctoniques selon la classe de taille et comparaison avec les valeurs de poids sec disponible dans la littérature. ${ }^{*}=$ selon l'espèce, $\mathrm{x}=$ taille de l'individu et $d=$ taille moyenne de l'individu dans l'échantillon utilise pour l'estimation du poids sec.

\begin{tabular}{|c|c|c|c|c|c|c|c|}
\hline $\begin{array}{c}\text { Zooplankton } \\
\text { Group }\end{array}$ & $\begin{array}{l}\text { Size } \\
\text { class } \\
(\mathrm{mm})\end{array}$ & \begin{tabular}{|c|} 
Number of \\
individual for \\
estimation \\
(this study)
\end{tabular} & $\begin{array}{c}\text { Calculated } \\
\text { dry weight } \\
(\mu \mathrm{g})(\text { this } \\
\text { study) }\end{array}$ & \begin{tabular}{|c|} 
Estimation \\
from Dumont \\
et al. (1975)
\end{tabular} & $\begin{array}{c}\text { Gonzales } \\
\text { et al. (2008) } \\
(\mu \mathrm{g})\end{array}$ & $\begin{array}{c}\text { Fetahi } \\
\text { et al. } \\
(2011) \\
(\mu g)\end{array}$ & $\begin{array}{c}\text { Michal- } \\
\text { oudi (2005) } \\
\text { ( } \mu \mathrm{g})\end{array}$ \\
\hline $\begin{array}{c}\text { Cladocera } \\
\text { Large }\end{array}$ & $>0.5$ & 1120 & 2.68 & & & $3.63 \pm 0.54$ & 1.4 to $3.1^{*}$ \\
\hline $\begin{array}{c}\text { Cladocera } \\
\text { Small }\end{array}$ & $\leq 0.5$ & 2739 & 0.73 & & & & 0.4 to $2.7^{*}$ \\
\hline $\begin{array}{l}\text { Cyclopoid } \\
\text { Large }\end{array}$ & $>0.5$ & 743 & 2.56 & $2.3 \pm 0.9$ & & $2.88 \pm 0.33$ & \\
\hline $\begin{array}{c}\text { Cyclopoid } \\
\text { Small }\end{array}$ & $\leq 0.5$ & 3624 & 0.72 & $0.5 \pm 0.4$ & & & \\
\hline Calanoid Large & $\geq 1.2$ & 615 & 16.75 & $19.0 \pm 7.4$ & 5 to $51^{*}$ & & \\
\hline $\begin{array}{l}\text { Calanoid } \\
\text { Medium }\end{array}$ & $\begin{array}{c}0.75 \leq x \\
x<1.25\end{array}$ & 1377 & 5.45 & $6.9 \pm 2.5$ & & & \\
\hline Calanoid Small & $x<0.75$ & 1299 & 1.54 & $1.9 \pm 1.0$ & & & \\
\hline Ostracoda & $d=0.5$ & 761 & 3.81 & & $\begin{array}{c}3.2 \\
\text { (Cypridae) }\end{array}$ & & \\
\hline Rotifera & $d=0.2$ & 1769 & 0.57 & & 0.025 to $4.2^{*}$ & & \\
\hline Nauplii & $\mathrm{d}=0.11$ & 5576 & 0.29 & & & $0.27 \pm 0.04$ & $\begin{array}{c}0.119 \text { to } \\
0.303^{*}\end{array}$ \\
\hline
\end{tabular}

physico-chemical parameters of the water (temperature, DO and depth of the oxycline), hydrometeorology parameters (season, rain, water level, wind and mixing period) The significance level for all statistical analyses was 0.05 . Statistical analyses were performed using R statistical software (version $\mathrm{n}^{\circ}$ 2.6.1, R Development Core Team 2011) and XLSTAT software.

\section{RESULTS}

\subsection{Water quality in the Nam Theun 2 Reservoir}

Surface water temperature varied from $18.5^{\circ} \mathrm{C}$ (at RES8 during the CD season) to $31.7^{\circ} \mathrm{C}$ (at RES4 during the WW season; Fig. 2). The seasonal pattern was the same for all the reservoir stations and no spatial variation appeared among the sampling stations. During the warm seasons, the reservoir water column is thermally stratified with a warm oxic epilimnion and a cooler anoxic hypolimnion. During the CD seasons or during floods, the reservoir water column overturns and the whole water column experienced a temperature decrease and homogenisation (Chanudet et al., same issue). The reservoir overturn generally occurred in December (except during the 20122013 CD season where it occurred in January 2013). Dissolved oxygen (DO) concentrations showed spatial and 


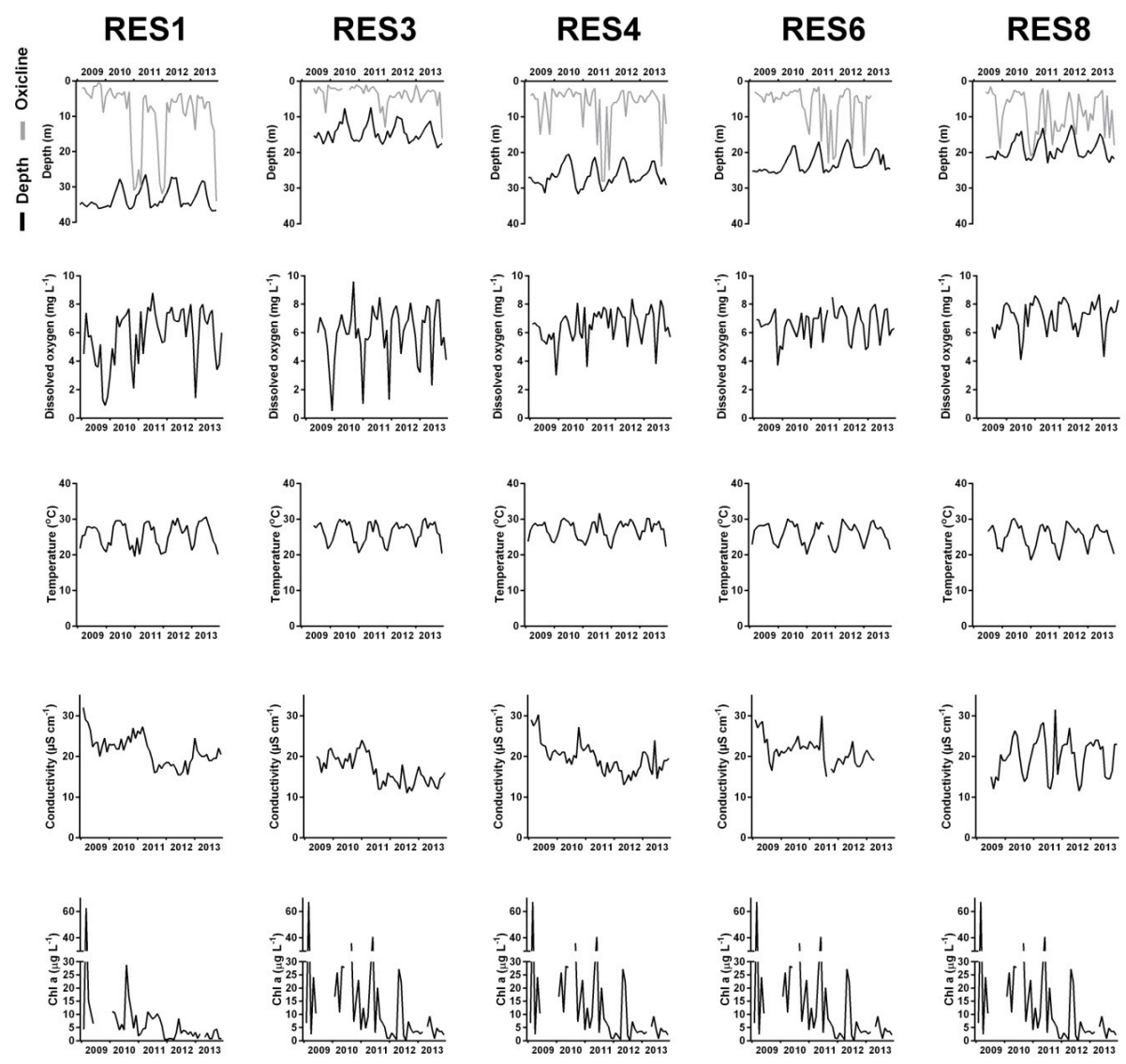

Fig. 2. Temporal evolution of main physico-chemical parameters on sub-surface from 2009 to 2013 at the monitoring stations.

Fig. 2. Évolution temporelle des principaux paramètres physico-chimiques en sub-surface de 2009 à 2013 aux stations du monitoring.

temporal variations (Fig. 2). At RES1, RES4 and RES6, the thickness of the surface oxic layer increased from nearly $0.5 \mathrm{~m}$ in 2008 to $5 \mathrm{~m}$ in 2013. In 2010 and 2011, high floods induced a significant increase of the oxygenation at the end of the year. RES3 which is an isolated sheltered area and RES 8 which is under the influence of tributaries, showed respectively a lower evolution and no significant evolution of the thickness of the DO concentrations. The DO concentrations in RES1 and RES3 ranged from $0.5 \mathrm{mg} . \mathrm{L}^{-1}$ ( $5 \%$ saturation) to $9.6 \mathrm{mg} \cdot \mathrm{L}^{-1}(115 \%)$ over the study period. However, the low DO only occurred for a short period in December 2009 (water column mixing process). RES4, RES6 and RES8 had better surface oxygenation, ranging from 

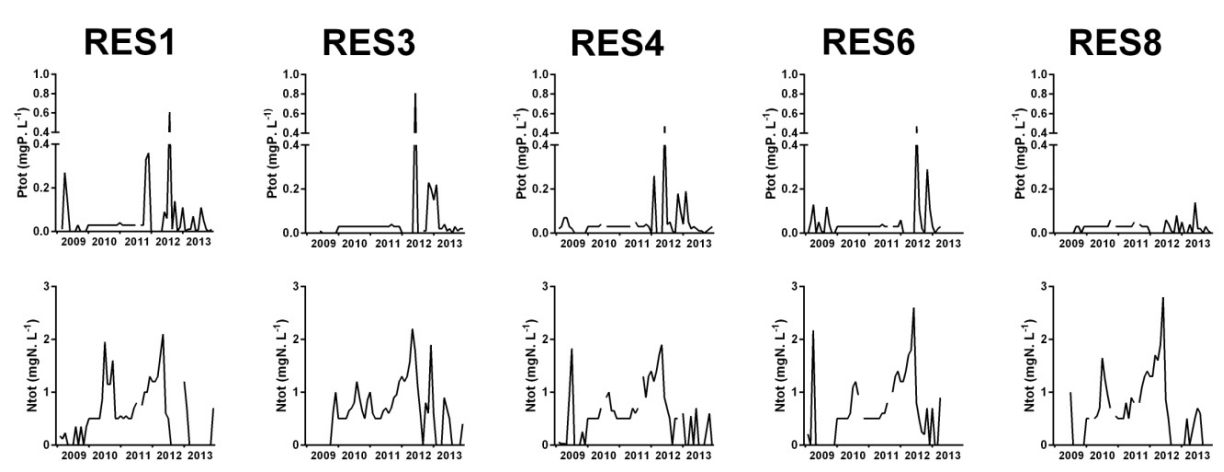

Fig. 3. Concentrations in Total Phosphorous (Ptot) and total Nitrogen (Ntot) from 2009 to 2013 at the monitored stations.

Fig. 3. Concentrations en phosphore total (Ptot) et azote total (Ntot) de 2009 à 2013 aux stations du monitoring.

$3.0 \mathrm{mg} . \mathrm{L}^{-1}(32 \%)$ to $8.7 \mathrm{mg} \cdot \mathrm{L}^{-1}(105 \%)$. The conductivity in surface water was always very low (monthly average values ranging from 11 at RES3 to $32 \mu \mathrm{S} . \mathrm{cm}^{-1}$ at RES1). The conductivity decreased during WW seasons and when the reservoir overturned. The highest values were recorded immediately after the impoundment until 2011 at RES1, RES3, RES4 and RES6 and slightly decreased the following years. In RES8, seasonal variation can be observed due to the influence of annual floods of the tributaries (Nam Theun and Nam On) but the range of concentrations is close to the others stations.

Annual peaks of chl a concentrations are observed during the stratification period (up to $67.4 \mu \mathrm{g} . \mathrm{L}^{-1}$ at RES3) at the end of the WD season, with highest concentrations during the first two years (Fig. 2) and at RES1 and RES3. The rest of the year, values remained around $10 \mu \mathrm{g} . \mathrm{L}^{-1}$. Ptot concentrations measured in the reservoir were low until 2011 (from 0.01 to $0.06 \mathrm{mgP} . \mathrm{L}^{-1}$; Fig. 3), expect during the first month after impoundment in RES1 (up to 0.27 mgP. $L^{-1}$ ). In 2012, Ptot concentrations showed the highest values with a maximum of average value across stations in June 2012 at 0.27 mgP.L ${ }^{-1}$. Then, Ptot concentrations decreased again in 2013 except in RES8. Ntot concentrations were close to $0 \mathrm{mgN} / \mathrm{L}$ at the beginning of the impoundment and increased at the end of 2009. Mean monthly Ntot concentrations ranged from 0 to $2.83 \mathrm{mgN}^{-1}$ and no clear spatial pattern appeared among sampling stations. Two peaks occurred in June 2011 in RES6 (7.1 mgN.L ${ }^{-1}$ ) and in December 2012 in RES4 (9.6 mgN.L ${ }^{-1}$ ). After an upsurge period of two years (2009-2011), the NT2 Reservoir evolved to an oligo-mesotrophic status (Martinet et al., same issue).

\subsection{Zooplankton population dynamics}

Figure 4 shows the temporal evolution of total densities and biomasses for 

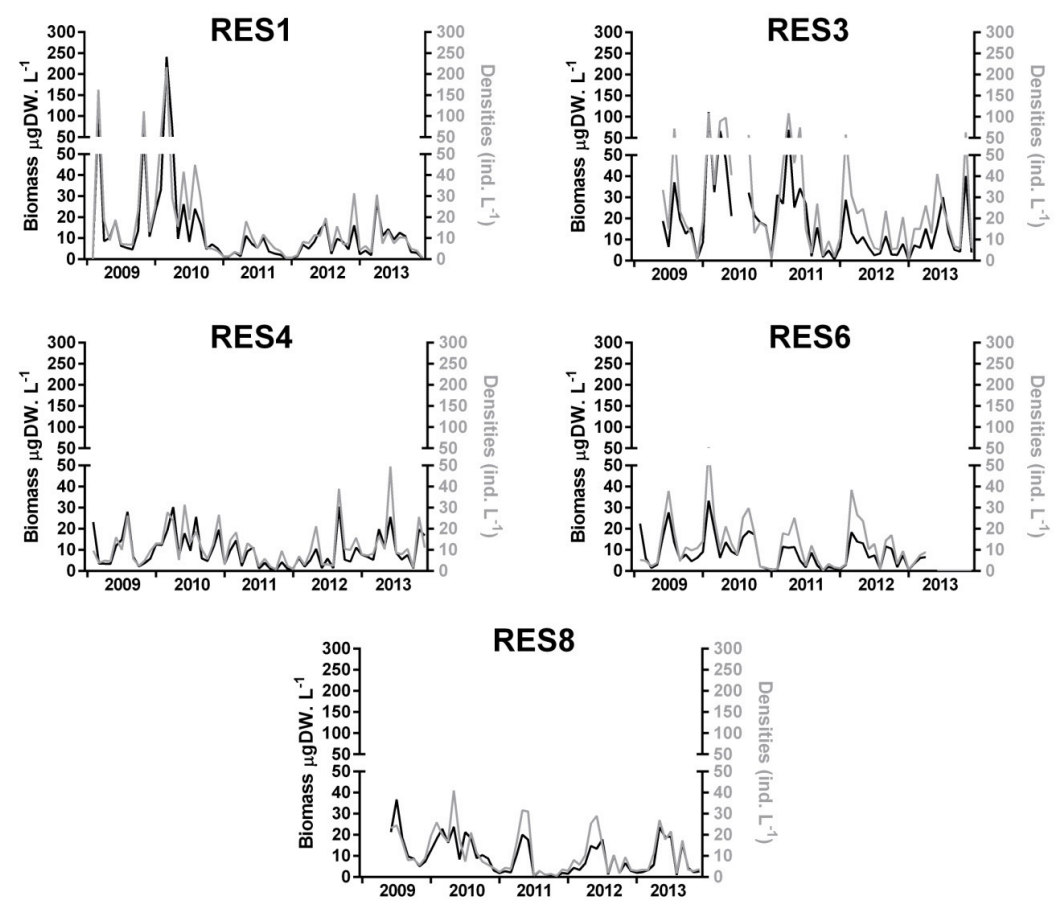

Fig. 4. Zooplankton biomasses and densities from 2009 to 2013 for the monitored stations.

Fig. 4. Biomasses et densités du zooplancton de 2009 à 2013 pour les stations du monitoring.

each sampling station. Globally, biomasses follow the same dynamic than the densities characterized by high monthly variations. Each year, three peaks were observed (up to 250 ind. $\mathrm{L}^{-1}$ and $250 \mu \mathrm{gW} \mathrm{L} \mathrm{L}^{-1}$ in RES1) (i) around March (end of the CD season), (ii) around September (end of the WW season) and (iii) in November (WD windy season). The dry and windy season peaks were more pronounced in 2013 compared to 2012. An annual disappearance of the zooplankton community occurred in December 2010, 2011 and 2013 and in January 2012 and can be related to the destratification of the water column (Fig. 4).
At the reservoir scale, the mean annual densities and biomasses of the zooplankton community (Tab. II, Tab. III and Fig. 4) reached a maximum in 2010 , two years after the reservoir filling. The average densities and biomasses in 2011, 2012 and 2013 were not significantly different but all were significantly lower than in 2010 (Kruskal-Wallis test, respectively $p=0.03 ; p=0.02$ and $p=$ 0.01 for densities and $p=0.001 ; p=$ 0.001 and $p=0.01$ for biomasses). While 2009 had high density and biomass, only biomass values were significantly higher than those in 2011 and in 2012 (Kruskal-Wallis test, respectively $p=0.04 ; p=0.03)$. Biomasses in 2010 
Table II. Annual average densities (ind. $\mathrm{L}^{-1} \pm$ SD) of zooplankton in NT2 reservoir from 2009 to 2013. Tableau II. Densités moyennes annuelles (ind. $\mathrm{L}^{-1} \pm \mathrm{SD}$ ) du zooplancton dans le réservoir de NT2 entre 2009 et 2013.

\begin{tabular}{|c|c|c|c|c|c|c|}
\hline & $\begin{array}{c}\text { RES1 } \\
\text { (ind. } L^{-1} \pm S D \text { ) }\end{array}$ & $\begin{array}{c}\text { RES3 } \\
\text { (ind. } L^{-1} \pm S D \text { ) }\end{array}$ & $\begin{array}{c}\text { RES4 } \\
\text { (ind. } \mathrm{L}^{-1} \pm \mathrm{SD} \text { ) }\end{array}$ & $\begin{array}{c}\text { RES6 } \\
\text { (ind. } L^{-1} \pm S D \text { ) }\end{array}$ & $\begin{array}{c}\text { RES8 } \\
\left.\text { (ind. } L^{-1} \pm S D\right)\end{array}$ & \begin{tabular}{|c|} 
Annual \\
average \\
(ind. $L^{-1} \pm S D$ )
\end{tabular} \\
\hline 2009 & $34.4 \pm 52.6$ & $\begin{array}{c}24.9 \pm 23.3 \\
\text { (last } 7 \text { months) }\end{array}$ & $9 \pm 6.9$ & $11.9 \pm 10.5$ & $\begin{array}{c}13.6 \pm 7.8 \\
\text { (last } 7 \text { months) }\end{array}$ & $18.7 \pm 28.6$ \\
\hline 2010 & $40.8 \pm 57.9$ & $49.7 \pm 36.9$ & $16.9 \pm 8.7$ & $18.3 \pm 14$ & $16.5 \pm 10.4$ & $27.7 \pm 33.5$ \\
\hline 2011 & $6 \pm 5.3$ & $29.7 \pm 33.9$ & $7.2 \pm 5.8$ & $8.9 \pm 8.4$ & $8.3 \pm 11.5$ & $12.4 \pm 19$ \\
\hline 2012 & $10.5 \pm 8.5$ & $18.8 \pm 15.2$ & $10.4 \pm 10.8$ & $13.5 \pm 11.5$ & $10.3 \pm 8.9$ & $12.7 \pm 11.4$ \\
\hline 2013 & $8.6 \pm 7.8$ & $19.5 \pm 17.7$ & $13.8 \pm 12.7$ & $\begin{array}{c}5.3 \pm 3.4 \\
\text { (first } 4 \text { months) }\end{array}$ & $9.7 \pm 8.9$ & $12.3 \pm 12.4$ \\
\hline
\end{tabular}

Table III. Annual average biomasses $\left(\mu \mathrm{g}\right.$ DW. $\mathrm{L}^{-1} \pm \mathrm{SD}$ ) of zooplankton in NT2 reservoir from 2009 to 2013.

Tableau III. Biomasses moyennes annuelles $\left(\mu \mathrm{g} D W . L^{-1} \pm S D\right)$ du zooplancton dans le réservoir de NT2 entre 2009 et 2013.

\begin{tabular}{|c|c|c|c|c|c|c|}
\hline & $\begin{array}{c}\text { RES1 } \\
\left(\mu \mathrm{g} \mathrm{DW} \mathrm{L}^{-1}\right. \\
\pm \mathrm{SD})\end{array}$ & $\begin{array}{c}\text { RES3 } \\
\left(\mu \mathrm{g} \mathrm{DW} \mathrm{L}^{-1}\right. \\
\pm \mathrm{SD})\end{array}$ & $\begin{array}{c}\text { RES4 } \\
\left(\mu \mathrm{g} \mathrm{DW} \mathrm{L}^{-1}\right. \\
\pm \mathrm{SD})\end{array}$ & $\begin{array}{c}\text { RES6 } \\
\left(\mu \mathrm{g} \mathrm{DW} \mathrm{L}^{-1}\right. \\
\pm \mathrm{SD})\end{array}$ & $\begin{array}{c}\text { RES8 } \\
\left(\mu \mathrm{g} \mathrm{DW} \mathrm{L}^{-1}\right. \\
\pm \mathrm{SD})\end{array}$ & $\begin{array}{c}\text { Annual average } \\
\text { ( } \mu \mathrm{g} \mathrm{DW} \mathrm{L}^{-1} \\
\pm \mathrm{SD})\end{array}$ \\
\hline 2009 & $23.3 \pm 34.7$ & $\begin{array}{c}15.9 \pm 11.6 \\
\text { (last } 7 \text { months) }\end{array}$ & $9.7 \pm 8.8$ & $10.4 \pm 8.5$ & $\begin{array}{c}15.4 \pm 11.2 \\
\text { (last } 7 \text { months) }\end{array}$ & $14.8 \pm 18.9$ \\
\hline 2010 & $39.1 \pm 66.2$ & $37.7 \pm 31.0$ & $14.7 \pm 8.0$ & $12.9 \pm 8.9$ & $14.4 \pm 6.6$ & $23.3 \pm 34.3$ \\
\hline 2011 & $4.2 \pm 3.6$ & $20.1 \pm 20.3$ & $5.2 \pm 4.8$ & $4.7 \pm 4.6$ & $5.2 \pm 6.9$ & $7.9 \pm 11.6$ \\
\hline 2012 & $7.9 \pm 5.6$ & $8.8 \pm 7.3$ & $7.1 \pm 8.1$ & $8.0 \pm 5.7$ & $7.0 \pm 5.7$ & $7.8 \pm 6.3$ \\
\hline 2013 & $8.4 \pm 7.7$ & $12.3 \pm 11.9$ & $11.3 \pm 7.4$ & $\begin{array}{c}4.3 \pm 2.8 \\
\text { (first } 4 \text { months) }\end{array}$ & $8.5 \pm 8.4$ & $9.7 \pm 8.7$ \\
\hline
\end{tabular}

were significantly higher than in other years for each sampling stations (see SM 1). The maximum annual mean density and biomass were reached respectively at RES3 in 2010 with 49.7 ind. $\mathrm{L}^{-1}$ and at RES1 in 2010 with $39.1 \mathrm{\mu g} \mathrm{DWL}^{-1}$ (Tab. II and Tab. III). The minimum mean density and biomass were recorded respectively at RES6 in 2013 with 5.3 ind. $\mathrm{L}^{-1}$ and at RES1 in 2011 with $4.2 \mu \mathrm{g} \mathrm{DW} \mathrm{L}^{-1}$. The results also highlight the spatial heterogeneity of the densities and biomasses into the reservoir during the first years of the monitoring. Whereas in 2009 and 2010 RES1 showed the highest densities and biomasses, since 2010, RES3 had the highest densities and since 2011 had the highest biomasses. Nevertheless, both densities and biomasses were not significantly different among stations and years in 2012 and 2013 (Kruskal-Wallis test, $p>0.05$; SM 1) underlining a homogenization of the community at the reservoir scale since this date.

Relative densities (Fig. 5) and relative biomasses (not shown) have a 


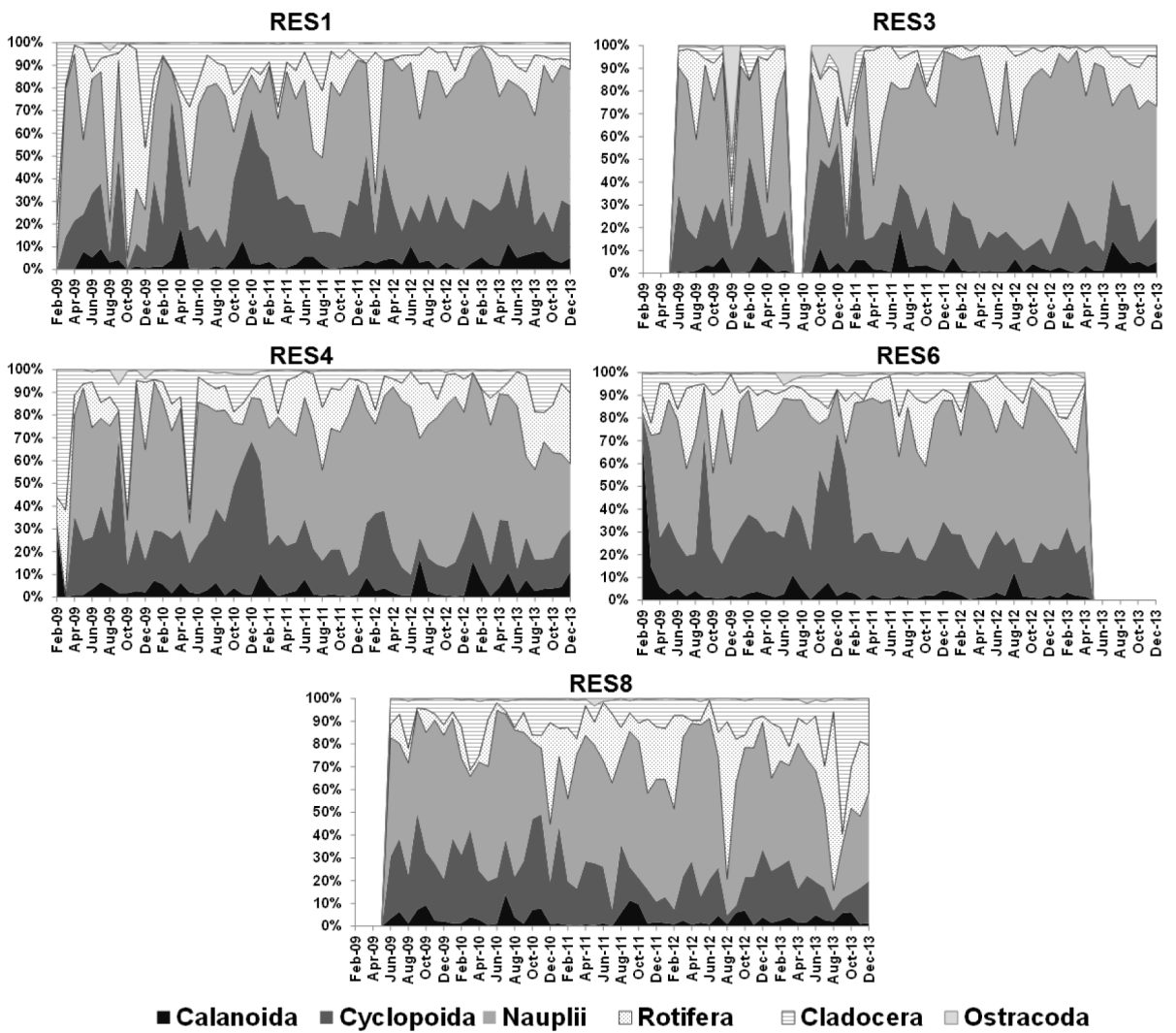

Fig. 5. Zooplanktonic groups relative density from 2009 to 2013 for the monitored stations.

Fig. 5. Densité relative des groupes zooplanctoniques de 2009 à 2013 pour les stations du monitoring.

similar pattern and highlight that the community was dominated by Copepods and especially the naupliar stage (mainly composed of Cyclopoids) and adults of Cyclopoids. RES4, RES6 and RES8 had a more stable composition of zooplankton than RES1 and RES3, where zooplankton group densities and biomasses varied substantially until 2011. At the inter-annual scale, Nauplii contributed between $46.0 \%$ (RES1) to $54.4 \%$ (RES6) to the total zooplankton densities (during the 5-year survey they contributed to $49.0 \% \pm 18.2 \%)$. Nauplii indicated a constant recruitment of the Copepod group. A short decrease of percentage of Nauplii appeared in October 2009 (4\%), March 2010 (11.3\%) and December 2010 (14.7\%). Calanoids, which were the largest individuals, had low average relative densities ranging from $3.2 \%$ at RES3 and RES 8 to $4.2 \%$ at RES4 (mean value of $3.7 \% \pm 5.6 \%$ ). High relative densities were recorded in February 2009 at RES4 (29\%) and RES6 (72.9\%) for this 
group. In the following years, only small increases of this population were observed at the end of the CD seasons (up to $12 \%$ of relative densities) and during the wet season 2013 which also contributed significantly to the biomass. Cladocera populations had a small contribution to the zooplankton community $(9.2 \% \pm 10.4 \%$ relative abundance over the study period), even though some peaks of density and biomass were observed, e.g. in February 2009 at RES1 (80.0\%) and RES4 (55.7\%), in October and May 2010 at RES4 $(60.8 \%)$ and in September 2013 at RES8 (59.6\%). The lowest relative density of Cladocera was observed at RES3 (3.6\%). Since 2001, the population declined excepted at RES4, RES6 and RES8 where the population remained stable. The total contribution of the Ostracoda population to the zooplankton abundances remained low for all the stations $(0.8 \% \pm 3.6 \%)$ during the monitoring except at RES3 in December 2009 and January 2011 where their contributions reached respectively $48 \%$ and $32.5 \%$. These periods corresponded to the mixing of the water column period. Finally, Rotifers, which are important as a food resource for fish juveniles, showed a relatively low contribution to the zooplankton community with an average value of $13.8 \% \pm 14.0 \%$ during the study period. The contribution of Rotifers ranged from $10.8 \%$ at RES6 to $15.3 \%$ at RES3 and RES8. Stable, but low densities and biomass were recorded during the $C D$ season just after the mixing period (DecemberFebruary).

\subsection{Environmental driving factors}

The zooplankton community was explored by PCA ordination based on biomasses. The two first axes explained a total variance of $44.4 \%$ (Fig. 6). The variables associated with this analysis explaining a high and significant proportion of variance were (i) on the first axis, the depth of the oxycline $(12.3 \%)$, the temperature $(8.5 \%)$, the mixing period $(8.1 \%)$ and the $\mathrm{Chl} \mathrm{a}$ concentration (7.1\%) and (ii) on the second axis meteorological variables with the mean monthly rain (17.9\%) and the season (12.8\%). The zooplankton community can be divided in two main clusters. The first cluster is composed of the Calanoids, Cyclopoids and Cladoreca that were negatively correlated to the depth of the oxycline (as well as the Nauplii; Fig. 6 and Tab. IV). The second cluster is composed of Ostracoda, Rotifera and Nauplii positively associated with temperature and $\mathrm{Chl} a$ and sensitive to physical variables (mixing period and wind). Rotifera population was also positively related to the season. Surprisingly, nutrients (Ntot and Ptot) and oxygen concentration variables were not significantly related with the zooplankton groups.

\section{DISCUSSION}

\subsection{Zooplankton community dynamics in the NT2 Reservoir}

From the beginning of the monitoring in 2009, the zooplankton community 


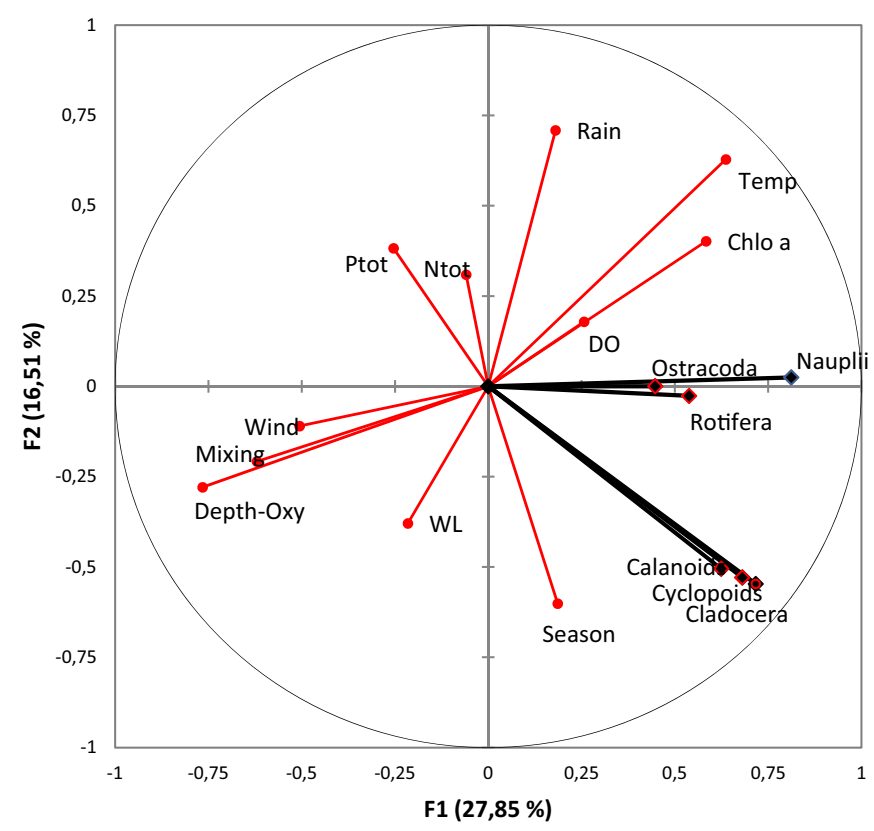

Fig. 6. Principal component analysis.

Fig. 6. Analyse en composante principale.

Table IV. Pearson correlation matrix from the PCA. In bold, correlations significantly different from 0 with alpha $=0.05$. WL $=$ water level, Chlo $a=$ Chlorophyll $a, \mathrm{DO}=$ dissolved oxygen, Temp $=$ temperature, Ntot $=$ total nitrogen, Ptot $=$ total phoshorus, Depth-Oxy $=$ depth of the oxycline.

Tableau IV. Matrice des corrélations de Pearson depuis l'ACP. Les valeurs en gras sont différentes de 0 à un niveau de signification alpha $=0,05 . \mathrm{WL}=$ niveau d'eau, Chlo $\mathrm{a}=$ Chlorophylle $\mathrm{a}, \mathrm{DO}=$ oxygen dissous, Temp $=$ température, Ntot $=$ azote total, Ptot $=$ phosphore total, Depth-Oxy $=$ profondeur de l'oxycline.

\begin{tabular}{|c|c|c|c|c|c|c|c|c|c|c|c|}
\hline Variables & Mixing & Season & WL & Chlo a & DO & Temp & Ntot & Ptot & Depth-Oxy & Rain & Wind \\
\hline Calanoids & -0.168 & 0.271 & 0.046 & 0.183 & -0.033 & 0.100 & -0.182 & -0.140 & -0.324 & -0.033 & -0.161 \\
\hline Cyclopoids & -0.218 & 0.270 & 0.081 & 0.278 & -0.029 & 0.060 & -0.126 & -0.188 & $-\mathbf{0 . 3 8 1}$ & -0.121 & -0.252 \\
\hline Nauplii & $-\mathbf{0 . 5 6 4}$ & 0.230 & -0.291 & $\mathbf{0 . 4 3 1}$ & $\mathbf{0 . 1 5 4}$ & $\mathbf{0 . 4 9 0}$ & 0.139 & -0.263 & $-\mathbf{0 . 6 1 3}$ & 0.062 & $-\mathbf{0 . 3 8 6}$ \\
\hline Rotifera & -0.267 & $\mathbf{0 . 3 3 2}$ & -0.205 & $\mathbf{0 . 3 2 6}$ & 0.157 & $\mathbf{0 . 3 2 5}$ & -0.065 & -0.120 & -0.259 & 0.018 & -0.181 \\
\hline Cladocera & -0.271 & 0.288 & 0.055 & 0.184 & 0.001 & 0.139 & -0.265 & -0.229 & $-\mathbf{0 . 4 1 3}$ & -0.112 & -0.208 \\
\hline Ostracoda & -0.046 & 0.066 & 0.005 & $\mathbf{0 . 5 3 8}$ & 0.062 & 0.161 & -0.084 & -0.295 & -0.317 & -0.036 & -0.319 \\
\hline
\end{tabular}

showed different phases of development mainly in line with the evolution of the reservoir water quality and hydrology. The first phase, occurring between 2009 and 2010, was a productive period linked to the trophic upsurge phenome- non observed after the first filling of the reservoir. During these 2 years, zooplankton showed the highest densities and biomasses, especially in 2010 at the end of the $C D$ season. Populations of Calanoids, and Rotifers, which are 
mainly herbivorous, and the omnivorous Cyclopoids were well-developed. Cladocera species, which are mainly detritivorous, took advantage of a high amount of particles directly linked to a high amount of nutrients and organic matter coming from the decomposition of drowned soil and vegetation. Ostracoda were not abundant but these species are mainly benthic and are generally under-represented in the water column. This high zooplankton production was enhanced by a low water renewal rate in the reservoir at this period (production started in March 2010). The peak observed during the end of the CD season 2010 was related to a combination of abiotic factors e.g. high temperature, lake stratification, low water level and the end of the period of the lowest water renewal rate, factors already qualified as important in zooplankton dynamics in shallow lakes (Rennella \& Quirós, 2006). The second phase occurred rapidly at the end of 2010 - beginning of 2011, and was highlighted by a decrease of annual zooplankton densities and biomasses. The decrease of zooplankton appeared during the last months of 2010 because of relatively low recruitment compared to that observed the previous year, especially at RES1. Seasonal peaks of density and biomass observed during the $C D$ season (highest productivity period) decreased. This could be explained by a higher water renewal rate at this time compared to the previous years at the same season. But the main negative effect on zooplankton communities appeared in 2011 after the exceptional rainy season. This high flooding event led to a faster renewal water rate which is a factor already known to affect zooplankton community (Nogueira, 2001) e.g. Rotifers or Copepods (Gonzales et al., 2008). Since 2012 the zooplankton population seems to have reached stabilization in terms of densities, biomasses and population composition. Zooplankton populations recovered from the flushing and dilution effects of the previous rainy season.

More globally, the NT2 annual average density was low in the main body of the reservoir (RES1, RES4, RES6 and RES8) compared to some other tropical reservoirs. However, values found in the NT2 Reservoir are in the range of the lowest values observed in the literature. For instance, Pinto-Coelho et al. (2005) found a mean density of 11.6 ind. $\mathrm{L}^{-1}$ for large oligotrophic tropical reservoirs. Other studies in tropical reservoirs indicated larger range of densities such as the Corumba Reservoir (Brazil) with densities between 0.5 to 447 ind. $\mathrm{L}^{-1}$ (Lansac-Toha et al., 2008) or in the Jurumirim Reservoir, an oligotrophic reservoir in Brazil, with densities between 1 to 1000 ind. $L^{-1}$ (Matsumura-Tundisi \& Tundisi, 1976). Biomass of the NT2 Reservoir could be compared to the biomass of Mourao Reservoir, an oligotrophic

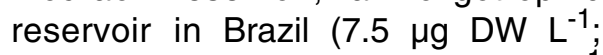
Bonecker et al., 2007) or $12.3 \mathrm{\mu g} \mathrm{DW} \mathrm{L}^{-1}$ for large oligotrophic tropical reservoirs (Pinto-Coelho et al., 2005). Based on the densities and biomasses found in the NT2 Reservoir compared to other studies in tropical reservoirs, the NT2 Reservoir can be qualified as oligotrophic. This trophic state is also supported by the observed size distribution of individuals. Zooplankton communities in the NT2 Reservoir have small 
body sizes, which is common in other oligotrophic tropical reservoir and lakes (e.g. South America; Gliwicz, 1994). For instance, the NT2 zooplanktonic community was dominated by small Copepods $(>80 \%$ of the population and occasionally by Cladocera up to $70 \%$ of the population) that could indicate an oligotrophic status (Matsumura-Tundisi \& Tundisi, 1976).

The high density of naupliar stages compared to the density of adults underlines that communities were maintained by a constant recruitment likely as a response to predation, food limitation or an unstable environment (strategy $r$ ). The small size of individuals is also known to be related to a topdown predation effect (Fetahi et al., 2011). Amazonian reservoirs were often dominated by Rotifers the years following the first filling (Arcifa, 1984) but they were not abundant in our survey. It is likely that the high fish biomass observed after the impoundment (Cottet et al., same issue) was supported as a result of high Rotifer predation. Nevertheless, the NT2 zooplankton community was dominated by Copepods (mainly Cyclopoida) which seems to be common in Asia (Dussart et al., 1984). This result is also in line with what has been observed by Horeau et al. (2005) in the Petit-Saut Reservoir in French Guiana.

\subsection{Environmental parameters influencing zooplankton communities}

The results of the PCA have shown a separation of the zooplanktonic community in two different clusters. The first cluster composed of Nauplii, Rotifer and Ostracoda, is related to $\mathrm{Chl} a$ and temperature. These populations are mainly composed of phytophage species and were linked to the phytoplankton production, itself highly seasonal. The Naupliar stage was also significantly negatively driven by the hydraulic factors like mixing period or wind leading to a nearly total disappearance of the population. Large mortalities of zooplankton following annual overturn have already been reported by Saunders \& Lewis (1988). On another hand, short-term disappearance of the zooplankton community can also be related to the decrease of the phytoplankton biomass (Martinet et al., same issue). The second cluster composed of Cladocera and Copepods (Cyclopoids and Calanoids) was mainly influenced by the depth of the oxycline, e.g. the dilution of the epilimnion.

These abiotic factors led to a spatial and temporal heterogeneity of the reservoir particularly during the first filling and the beginning of the operation phase. A clear longitudinal gradient was observed in 2009 and 2010. The RES3 sampling site is isolated from the main body of the reservoir and was protected from floods. The upstream sampling sites (RES6 and RES8) are clearly under the influence of the hydrology compared to the most downstream stations which are influenced by the mixing period, temperature and Chl a. No spatial difference was observed after 2011. This is in accordance with the study of Bonecker et al. (2007) that found no spatial variation of zooplankton biomass in relatively young Brazilian reservoirs (5, 12 and 40 years old). The theoretical model of Marzolf (1990) that predict higher zooplanktonic density 
toward the dam seems to be valid only for the first two years. This means that the influence of the current velocity was effective along the reservoir (lower current velocity at the dam site) during this period. Afterwards, other factors like temperature or mixing of the water column led to a homogenization of the habitat conditions. Bini et al. (1997) found similar results on limnological parameters. For instance, DO, pH and temperature did not explain longitudinal heterogeneity into their reservoir because of the low variation of these parameters along the axis. During the study period, no dramatic oxygen depletion events appeared in the NT2 Reservoir also minimizing the influence of the DO. Finally, no significant relation has been observed between the zooplankton community and nutrients. This can be due to low nutrient concentrations even during the peaks of zooplanktonic production. Nevertheless, densities and biomasses were correlated to $\mathrm{Chl}$ a with a high seasonal effect underlying the dominance of phytophage within the zooplantktonic community and a phytoplankton-based food chain in the NT2 Reservoir. As in these systems most of the energy transfer could come from both the phytoplankton and bacterioplankton (Havens, 2002), monitoring of bacterioplankton in the NT2 Reservoir may be of interest. The relationship of zooplankton community dynamics with fish pressure was not assessed in this study, but the rate of predation may influence zooplankton density and biomass. This could be particularly important during the beginning of the rainy season when zooplanktivorous fish focus on reproduction and decrease the predation pressure on Rotifera and Cladocera populations.

\section{CONCLUSION}

The filling of the NT2 Reservoir led to a change in the zooplanktonic community which is linked to the appearance of a thin oxygenated epilimnion and a large anoxic hypolimnion. The community was dominated by Copepods (including the Naupliar stage) over the study period. The spatial heterogeneity of the zooplanktonic community observed along a longitudinal gradient disappeared rapidly after the beginning of the operation phase and tend to stabilize. Nevertheless, the results highlighted a seasonal effect explained by a phytoplankton-based food chain. The zooplankton community of the NT2 Reservoir had low densities and biomasses compared to other tropical reservoirs and reflected oligotrophic conditions. They were significantly and negatively driven by the hydraulic factors like mixing period, temperature of the water or depth of the oxycline. Finally, the zooplankton community must be evaluated in order to anticipate the food availability for zooplanktivorous fish before developing a fish management plan.

\section{ACKNOWLEDGEMENT}

This research was conducted at the Aquatic Environment Laboratory of Nam Theun 2 Power Company in Lao PDR whose Shareholders are Électricité de France, Lao Holding State Enterprise and Electricity Generating Public Company Limited of Thailand. 
We would like to thank all the NTPC teams for their support during this monitoring program with a special thanks to the hydrobiology team, especially Ms Sadavee S.Phabmixay, and chemistry team from the WQB Dept for their support in chemistry analysis. We would like also to thank Mr Liankham Payasane (GIS team), the logistic team with their useful boat drivers and Ms Leah Bêche who reviewed and improved this version of the manuscript as a native English speaker.

\section{REFERENCES}

American Public Health Association. APHA, 1995. Standard methods for the examination of water and wastewater. American Public Health Association, American Water Works association, Water Environment Federation, Washington.

Araujo H.M.P., Nascimento-Vieira D.A., Neumann-Leitão S., Schwamborn R., Lucas A.P.O. \& Alves J.P.H., 2008. Zooplankton community dynamics in relation to the seasonal cycle and nutrient inputs in an urban tropical estuary in Brazil. Brazil. J. Biol. 68(4) : 751-762.

Arcifa M.S., 1984. Zooplankton composition of ten reservoirs in southern Brazil. Hydrobiol. 113(1) : 137-145.

Bernot R.J., Dodds W.K., Quist M.C. \& Guy C.S., 2004. Spatial and temporal variability of zooplankton in a great plains reservoir. Hydrobiol. 525(1-3) : 101-112.

Bini L.M., Tundisi J.G., Matsumura-Tundisi T. \& Matheus C.E., 1997. Spatial variation of zooplankton groups in a tropical reservoir (Broa Reservoir, São Paulo State-Brazil). Hydrobiol. 357 : 89-98.

Bonecker C.C., Nagae M.U., Bletller M.C.M., Velho L.F.M. \& Lansac-Tôha F.A., 2007. Zooplantkon biomass in tropical reservoirs in southern Brazil. Hydrobiol. 579 : 115-123.
Chanudet V., Fabre V. \& Van Der Kaaij T., 2012. Application of a three-dimentional model to the Nam Theun 2 Reservoir (Lao PDR). J. Great Lakes Res. 38 : 260-269.

Chanudet V., Guédant P., Rode W., Guérin F., Serça D., Deshmukh C. \& Descloux $\mathrm{S}$. Evolution of the physico-chemical water quality in the Nam Theun 2 Reservoir for the first 5 years after impoundment. Hydroécol. Appl. 19 (same issue).

Cottet M., Descloux S., Guedant P., Cerdan P. \& Vigouroux R. Fish Population dynamic in the newly impounded Nam Theun 2 Reservoir (Lao PDR). Hydroécol. Appl. 19 (same issue).

Descloux S., Chanudet V., Poilvé H. \& Grégoire A., 2011. Co-assessment of biomass and soil organic carbon stocks in a future reservoir area located in Southeast Asia. Environ. Monit. Assess.173 : 723-741.

Descloux S., Guédant P., Phommachanh D. \& Luthi R., 2014. Main features of the Nam Theun 2 hydroelectric project (Lao PDR) and the associated environmental monitoring programme. Hydroécol. Appl. 19 (same issue).

Development Core Team, 2011 R: A language and environment for statistical computing. R Foundation for Statistical Computing, Vienna, Austria. ISBN 3900051-07-0, http://www.R-project.org/. Accessed 12 Jan 2011.

Dumont H.J., Van de Velde I. \& Dumont S., 1975. The dry weight estimate of biomass in a selection of Cladocera, Copepoda and Rotifera from the plankton, periphyton and benthos of continental waters. Oecologia 19 : 75-97.

Dussart B.H., Fernando C.H., MatsumuraTundisi T. \& Shiel R.J., 1984. A review of systematics, distribution and ecology of tropical freshwater zooplankton. In Tropical Zooplankton (pp. 77-91). Springer Netherlands. 
Espíndola E.L.G., Matsumura-Tundisi T., Rietzler A.C. \& Tundisi J.G., 2000. Spatial heterogeneity of the Tucuruí reservoir (State of Pará, Amazonia, Brazil) and the distribution of zooplanktonic species. Revista Brasileira de Biologia 60(2) : 179-194.

Fernando C.H., 2002. Guide to tropical freshwater zooplankton: identification, ecology and impact on fisheries. In Guide to tropical freshwater zooplankton: identification, ecology and impact on fisheries. Backhuys.

Fetahi T., Mengistou S. \& Schagerl M., 2011. Zooplankton community structure and ecology of the tropical-highland Lake Hayq, Ethiopia. Limnol. 41 : 389-397.

Frontier S., 1972. Calcul de l'erreur sur un comptage de zooplancton. J. Exp. Mar. Biol. Ecol. 8 : 121-132.

Gliwicz Z.M., 1994. Relative significance of direct and indirect effects of predation by planktivorous fish on zooplankton. Hydrobiol. 272(1-3) : 201-210.

González E.J., Matsumura-Tundisi T. \& Tundisi J.G., 2008. Size and dry weight of main zooplankton species in Bariri reservoir (SP, Brazil). Brazilian J. Biology 68(1) : 69-75.

Hairston Jr N.G \& Fussman G.F., 2002. Lake Ecosystems. Encyclopodia of Life Science. Mcmillan Publishers Ltd, Nature Publishing Group.

Hart R.C., 1990. Zooplankton distribution in relation to turbidity and related environmental gradients in a large subtropical reservoir: patterns and implications. Freshwater Biol. 24(2) : 241-263.

Havens K.E., 2002. Zooplankton structure and potential food web interactions in the plankton of a subtropical chain-oflakes. The Scientific World Journal 2 : 926-942.

Horeau V., Richard S., Vigouroux R., Guillemet L. \& Cerdan P., 2005. Variabilités spatiales et temporelles de la qualité physico-chimique et des invertébrés pélagiques des eaux de la retenue hydroélectrique de Petit Saut (Guyane française). J. Water Science 18 : 109-126.

Lansac-Tôha F.A, Bini L.M., Velho L.F.M., Bonecker C.C., Takahashi E.M. \& Vieira L.C.G., 2008. Temporal coherence of zooplankton abundance in a tropical reservoir. Hydrobiol. 614 : 387-399.

Mageed A.A.A., \& Heikal M.T., 2006. Factors affecting seasonal patterns in epilimnion zooplankton community in one of the largest man-made lakes in Africa (Lake Nasser, Egypt). Limnologica - Ecology and Management of Inland Waters 36(2) : 91-97.

Martinet M., Guédant P. \& Descloux S. Phytoplankton community and trophic status assessment of a newly impounded sub-tropical reservoir: case study of the Nam-Theun 2 Reservoir (Lao PDR, South-East Asia). Hydroécol. Appl. 19 (same issue).

Marzolf G.R., 1990. Reservoirs as environments for zooplankton. In: Reservoir Limnology: Ecological Perspectives. John Wiley \& Sons, New York, pp. 195-208.

Matsumura-Tundisi T. \& Tundisi J.G., 1976. Plankton studies in a lacustrine environment. Oecologia 25(3) : 265-270.

Michaloudi E., 2005. Dry weights of the zooplankton of Lake Mikri Prespa (Macedonia, Greece). Belgian Journal of Zoology 135(2) : 223-227.

MRC, 2010. State of the Basin Report 2010. Mekong River Commission, Vientiane, Lao PDR,123 p.

Nogueira M.G., 2001. Zooplankton composition, dominance and abundance as indicators of environmental compartmentalization in Jurumirim Reservoir (Paranapanema River), São Paulo, Brazil. Hydrobiol. 455(1-3) : 1-18.

Pinto-Coelho R., Pinel-Alloul B., Méthot G. \& Havens K.E., 2005. Crustacean zooplankton in lakes and reservoirs of temperate and tropical regions: variation 
with trophic status. Can. J. Fish. Aquat. Sci. 62 : 348-361.

Rennella A.M. \& Quirós R., 2006. The effects of hydrology on plankton biomass in shallow lakes of the Pampa Plain. Hydrobiol. 556(1) : 181-191.

Saunders III J.F., \& Lewis Jr W.M., 1988. Zooplankton abundance and transport in a tropical white-water river. Hydrobiol. 162(2) : 147-155.

Schulz K.L. \& Sterner R.W., 1999. Phytoplankton phosphorus limitation and food quality for Bosmina. Limnol. Oceanogr. 44 : 1549-1556.

Seda J. \& Devetter M., 2000. Zooplankton community structure along a trophic gradient in a canyon-shaped dam reservoir. J. Plankton Res. 22(10) : 1829-1840.
Sousa F.D.R., Elmoor-Loureiro L.M.A., Medonça-Galvaõ L. \& Pujol-Luz J.R., 2014. Evaluation of a new sampling method for assessing Cladocera richness (Crustacea, Branchiopoda) in macrophyte-rich wetlands. Ann. Limnol. - Int. J. Lim. 50 : 143-153.

Starling F.D.R., 2000. Comparative study of the zooplankton composition of six lacustrine ecosystems in Central Brazil during the dry season. Rev. Brasileira de Biologia, 60(1) : 101-111.

Uku J.N., \& Mavuti K.M., 1994. Comparative limnology, species diversity and biomass relationship of zooplankton and phytoplankton in five freshwater lakes in Kenya. Hydrobiol. 272(1-3) : 251-258. 